\title{
Telmisartan protects central neurons against nutrient deprivation-induced apoptosis in vitro through activation of PPARY and the Akt/GSK-3ß pathway
}

\author{
Tao PANG ${ }^{1,2,3, \#, ~ L i-x i n ~ S U N}{ }^{1, \#}$, Tao WANG ${ }^{1}$, Zhen-zhou JIANG ${ }^{1}$, Hong LIAO ${ }^{1,2, *}$, Lu-yong ZHANG ${ }^{1,2, *}$ \\ ${ }^{1}$ New Drug Screening Center, China Pharmaceutical University, Nanjing 210009, China; ${ }^{2}$ State Key Laboratory of Natural Medicines, \\ China Pharmaceutical University, Nanjing 210009, China; ${ }^{3}$ Key Laboratory of Drug Quality Control and Pharmacovigilance (China \\ Pharmaceutical University), Ministry of Education, Nanjing 210009, China
}

\begin{abstract}
Aim: To determine whether angiotensin II receptor blockers (ARBs) could protect central neurons against nutrient deprivation-induced apoptosis in vitro and to elucidate the underlying mechanisms.

Methods: Primary rat cerebellar granule cells (CGCs) underwent B27 (a serum substitute) deprivation for $24 \mathrm{~h}$ to induce neurotoxicity, and cell viability was analyzed using LDH assay and WST-1 assay. DNA laddering assay and TUNEL assay were used to detect cell apoptosis. The expression of caspase-3 and Bcl-2, and the phosphorylation of Akt and GSK-3 $\beta$ were detected using Western blot analysis. $\mathrm{AT}_{1 \mathrm{a}}$ mRNA expression was determined using RT-PCR analysis.

Results: B27 deprivation significantly increased the apoptosis of CGCs, as demonstrated by LDH release, DNA laddering, caspase-3 activation and positive TUNEL staining. Pretreatment with $10 \mu \mathrm{mol} / \mathrm{L}$ ARBs (telmisartan, candesartan or losartan) partially blocked B27 deprivation-induced apoptosis of CGCs with telmisartan being the most effective one. B27 deprivation markedly increased the expression of $\mathrm{AT}_{1 \mathrm{a}}$ receptor in CGCs, inhibited Akt and GSK-3 $\beta$ activation, decreased Bcl-2 level, and activated caspase-3, which were reversed by pretreatment with $1 \mu \mathrm{mol} / \mathrm{L}$ telmisartan. In addition, pretreatment with $10 \mu \mathrm{mol} / \mathrm{L}$ PPARy agonist pioglitazone was more effective in protecting CGCs against B27 deprivation-induced apoptosis, whereas pretreatment with 20 mmol/L PPARY antagonist GW9662 abolished all the effects of telmisartan in CGCs deprived of B27.

Conclusion: ARBs, in particular telmisartan, can protect the nutrient deprivation-induced apoptosis of CGCs in vitro through activation of PPARy and the Akt/GSK-3ß pathway.
\end{abstract}

Keywords: cerebellar granule cell; nutrient deprivation; apoptosis; angiotensin II receptor blocker; telmisartan; $\mathrm{AT}_{1 \mathrm{a}}$ receptor; $\mathrm{Akt}$ GSK-3ß; PPARY; neurotoxicity

Acta Pharmacologica Sinica (2014) 35: 727-737; doi: 10.1038/aps.2013.199; published online 5 May 2014

\section{Introduction}

The renin-angiotensin system (RAS), including angiotensinogen, renin, angiotensin converting enzyme and angiotensin II (Ang II), exists in both the peripheral nervous system and the brain $^{[1]}$. The brain RAS plays an important role in the regulation of neurogenic hypertension ${ }^{[2]}$, strokes $^{[3]}$, depression ${ }^{[4]}$, and other neurodegenerative diseases, such as Alzheimer's disease $^{[5,6]}$ and Parkinson's disease ${ }^{[7]}$. There are two types of

\footnotetext{
\# These authors contributed equally to this work.

* To whom correspondence should be addressed.

E-mail lyzhang@cpu.edu.cn (Lu-yong ZHANG); liaohong56@hotmail.com (Hong LIAO)

Received 2013-10-04 Accepted 2013-12-30
}

Ang II receptors, $\mathrm{AT}_{1}$ and $\mathrm{AT}_{2}$ receptors, and $\mathrm{AT}_{1}$ receptors mediate most of the physiological and pathological effects of Ang II. Recent studies have indicated that the administration of $\mathrm{AT}_{1}$ receptor blockers (ARBs) significantly lowers the risk of stroke owing to the neuroprotective effects of these drugs ${ }^{[8-10]}$.

Most of the ARBs, which are collectively referred to as sartans, are biphenyl-tetrazole derivatives with similar, but not identical, pharmacological profiles ${ }^{[11]}$. Among the ARBs, the biphenyl-nontetrazole telmisartan is structurally unique and possesses $\mathrm{AT}_{1}$ receptor blocking and partial peroxisome proliferator-activated receptor gamma (PPARY) activating properties $^{[12]}$. PPARY is an intracellular nuclear hormone receptor that regulates multiple pathways involved in carbohydrate and lipid metabolism ${ }^{[13]}$, as well as neurological diseases ${ }^{[14]}$. 
The differentiated neurons in the central nervous system (CNS) require nutrients, including serum, to survive against apoptosis and to exert their functions ${ }^{[15,16]}$. The nutrients in serum activate the phosphatidylinositol-3 kinase (PI-3K)/ Akt pathway, which is an important signal transduction pathway involved in the survival of neurons ${ }^{[17]}$, while Akt phosphorylates and inhibits glycogen synthase kinase-3 $\beta$ (GSK-3 $\beta)^{[18]}$, which is required for apoptosis in neurons ${ }^{[19]}$. In several brain diseases, such as traumatic brain injury (TBI), stroke and chronic neurodegenerative diseases, there are insufficient nutrients to support neuron survival, resulting in neuronal death. The main type of neuronal death is apoptosis induced by nutrient depletion. The PI-3K/Akt/GSK-3 $\beta$ pathway has also been shown to play important roles in glutamate-induced apoptosis ${ }^{[20,21]}$. Compounds, such as lithium, have been reported to prevent glutamate-induced neuronal death by regulating these pathways ${ }^{[21,22]}$.

Recently, it has been shown that ARBs significantly ameliorate the neurological outcome of TBI, stroke and Alzheimer's disease, which are associated with insufficient nutrients ${ }^{[23-25]}$. Therefore, we hypothesized that ARBs may directly protect neurons from nutrient deprivation-induced neuronal death. To further clarify the mechanisms of the direct neuroprotective effects of ARBs in neurons, we studied the effects of ARBs in rat cerebellar granule neuron cells (CGCs), one of the most widely used in vitro experimental models used to study neuronal cell death. CGCs can survive in the presence of the nutrient B27, a serum substitute. If the B27 is removed, the majority of CGCs will die through an apoptotic process ${ }^{[22,26]}$.

In particular, we focused on telmisartan as an ARB prototype because of its reported pleiotropic neuroprotective effects as an $\mathrm{AT}_{1}$ receptor antagonist and a PPARY agonist in in vivo animal models of stroke and Alzheimer's disease ${ }^{[24,25]}$. We investigated whether telmisartan protects the CGCs from death induced by nutrient deprivation and the mechanisms involved in these neuroprotective effects.

\section{Materials and methods Materials}

Cell culture medium and supplements were obtained from Invitrogen (Carlsbad, CA, USA). Telmisartan, losartan and GW9662 were purchased from Sigma-Aldrich (St Louis, MO, USA). The following primary antibodies were used for Western blot analysis: rabbit anti- $\beta$-actin (1:1000), rabbit anticaspase 3 (1:1000), rabbit anti-cleaved caspase 3 (1:1000), rabbit anti-phospho-Akt (Ser473) (1:1000), rabbit anti-phosphoGSK-3 $\beta$ (Ser9) (1:1000) and rabbit anti-Bcl-2 (1:1000). All antibodies were purchased from Cell Signaling Technology (Danvers, MA, USA). The following secondary antibodies were used for Western blot analysis: donkey anti-rabbit IgG (1:5000, Amersham BioSciences, Piscataway, NJ, USA) and goat antimouse IgG (1:10000, Jackson ImmunoResearch, West Grove, PA, USA). SuperSignal West Dura Substrate was used for chemiluminescent detection and was purchased from Thermo Fisher Scientific (Pittsburg, PA, USA). All other chemicals were obtained from Sigma-Aldrich unless otherwise stated.

\section{Animals}

Eight-day old Sprague-Dawley male and female pups and their mothers were purchased from the Experimental Animal Center of Soochow University (Suzhou, Jiangsu, China). Wildtype C57BL6/J and $\mathrm{AT}_{1 \mathrm{a}}$ knock-out B6.129P2-Agtr1atm1Unc/J mice were obtained from the Jackson Laboratory (Bar Harbor, MA, USA) and were used to breed the 6-d old pups, respectively. These mice were backcrossed for more than 10 generations to the parental inbred strain. One male and one female were kept in each cage at $22^{\circ} \mathrm{C}$ under a $12: 12 \mathrm{~h}$ dark-light cycle and were given free access to water and breeder chow. Animal housing and handling were carried out in accordance with the US National Institutes of Health (NIH) Guide for the Care and Use of Laboratory Animals, which is published by the US National Academy of Sciences (http://oacu.od.nih. gov/regs/index.htm). All experimental procedures were approved by the Administration Committee of Experimental Animals, Jiangsu Province and China Pharmaceutical University.

\section{Primary rat CGCs cultures}

CGCs were isolated from 8-d old Sprague-Dawley rat pups, as previously described ${ }^{[27]}$. Cerebella were collected and placed in ice-cold Hanks' balanced salt solution (Invitrogen). After removal of the meninges, the cerebella were dispersed in the same buffer containing $0.25 \%$ trypsin (Invitrogen) and digested for $15 \mathrm{~min}$ at $37^{\circ} \mathrm{C}$. Trypsin digestion was stopped by the addition of two volumes of DMEM (Invitrogen) supplemented with 10\% fetal bovine serum (FBS) (Invitrogen) and $0.1 \mathrm{mg} / \mathrm{mL}$ DNase I (Sigma-Aldrich). After gentle trituration, the digested tissues were centrifuged at $1000 \times$ rounds $/ \mathrm{min}$ for $5 \mathrm{~min}$. The cell pellets were resuspended in complete Neurobasal culture medium (Invitrogen) supplemented with 2\% B27 (Invitrogen) and $0.5 \mathrm{mmol} / \mathrm{L}$ GlutaMax (Invitrogen). After filtration through a $70 \mu \mathrm{m}$ cell strainer (BD Falcon, Vernon Hills, IL, USA), the cells were plated at a density of $1 \times 10^{6}$ cells $/ \mathrm{mL}$ in poly-L-lysine coated plates (Becton Dickinson and Company, Franklin Lakes, NJ, USA) or glass chamber slides (Nalge Nunc International, Naperville, IL, USA). The cultures were incubated in a humidified atmosphere of $5 \% \mathrm{CO}_{2} / 95 \%$ air at $37^{\circ} \mathrm{C}$. Cytosine arabinofuranoside $(10 \mu \mathrm{mol} / \mathrm{L})$ was added to the cultures $24 \mathrm{~h}$ after plating to arrest the growth of the glia cells. Cultures at 6-8 d in vitro (DIV) were used in this study. Immunocytochemical validation with anti-MAP2 antibody and 4',6-diamidino-2-phenylindole (DAPI) revealed that more than $95 \%$ of the cells in our culture system were neurons at the time of experiment.

\section{Cell culture treatments}

Excitotoxicity was induced by B27 deprivation for $24 \mathrm{~h}$ for the various assays. To determine whether $\mathrm{AT}_{1}$ receptor was involved in nutrient deprivation-induced cell death, the cells were pretreated with either telmisartan or losartan $\left(\mathrm{AT}_{1}\right.$ receptor antagonist) for $24 \mathrm{~h}$. To determine whether PPARY was involved in the neuroprotective effects of telmisartan or losartan, the PPARY antagonist GW9662 was added $1 \mathrm{~h}$ prior to 
telmisartan or losartan treatment.

\section{Measurement of lactate dehydrogenase (LDH) activity}

Cell viability was quantified by measuring the LDH activity. Cells pretreated with telmisartan, candesartan or losartan were incubated under nutrient deprivation conditions for $24 \mathrm{~h}$. The cell-free culture supernatants were collected at the end of incubation to determine the LDH activity using the LDH Cytotoxicity Assay Kit (Cayman Chemical, detailed imformation) according to the manufacturer's instructions. The data were normalized to the activity of LDH released from the vehicletreated cells $(100 \%)$ and are expressed as a percentage of the control.

\section{WST-1 assay}

The viability of the CGCs was also evaluated using the WST-1 colorimetric assay kit (Beyotime, Nanjing, China) according to the manufacturer's instructions. WST-1 is a water-soluble tetrazolium salt, and the rate of WST-1 cleavage by mitochondrial dehydrogenases is correlated with the number of viable cells. Briefly, cells cultured in a 96-well plate were pretreated with telmisartan, candesartan or losartan for $24 \mathrm{~h}$, followed by nutrient deprivation. After $21 \mathrm{~h}$ of nutrient deprivation, $10 \mu \mathrm{L}$ of WST-1 was added to the $100 \mu \mathrm{L}$ of culture medium in each well, and the incubation was continued for an additional $3 \mathrm{~h}$. The optical density was measured at $450 \mathrm{~nm}$ with a reference wavelength of $650 \mathrm{~nm}$. The control was normalized to $100 \%$ for each assay, and the treatments are expressed as the percentage of the control.

\section{Western blot analysis}

To determine the levels of phospho-proteins, the cells were lysed in Tris-Glycine SDS lysis buffer (Invitrogen) at the indicated time points after B27 removal, and the lysates were boiled for $10 \mathrm{~min}$. For other protein blots, cell lysates were prepared $24 \mathrm{~h}$ after the B27 removal. The whole cell extracts were separated by electrophoresis on 10\% SDS-PAGE gels and transferred onto PVDF membranes. The membranes were blocked for $1 \mathrm{~h}$ in a casein-based blocking buffer (SigmaAldrich) and incubated overnight at $4^{\circ} \mathrm{C}$ with the primary antibody, followed by washing and exposure to the secondary antibody for $30 \mathrm{~min}$ at room temperature. $\beta$-Actin was used as a loading control for the whole cell samples. The membranes were exposed to SuperSignal West Dura Substrate for chemiluminescent detection. The resulting bands were quantified using densitometric analysis and were normalized to the levels of $\beta$-actin protein.

\section{Real-time PCR}

To determine the levels of gene expression, total RNA was isolated at the indicated times using $1 \mathrm{~mL}$ of TRIzol (Invitrogen), followed by purification using an RNeasy Mini kit (Qiagen, Valencia, CA, USA) according to the manufacturer's instructions. Synthesis of complementary DNA (cDNA) was performed using $0.8 \mu \mathrm{g}$ of total RNA and the Super-Script III firstStrand Synthesis kit (Invitrogen). Quantitative real-time poly- merase chain reaction (qPCR) was performed on a Real-Time PCR Detection System (PTC-200, BioRad) with the SYBR Green PCR Master Mix (Applied Biosystems, Foster City, CA, USA). qPCR was performed in a $20 \mu \mathrm{L}$ reaction mixture containing $10 \mu \mathrm{L}$ of SYBR Green PCR Master Mix, $4 \mu \mathrm{L}$ of cDNA and 0.3 $\mu \mathrm{mol} / \mathrm{L}$ of each primer for a specific $\mathrm{AT}_{1 \mathrm{a}}$ gene. The following specific primers were used: $\mathrm{AT}_{1 \mathrm{a}}$ (Forward: 5'-AGCCTGCGTCTTGTTTTGAG-3' and reverse: 5'-GCTGCCCTGGCTTCTGTC-3') and GAPDH (Forward: 5'-ATGACTCTACCCACGGCAAG-3' and reverse: 5'-TGGAAGATGGTGATGGGTTT-3'). The remaining reagents for RNA isolation and reverse transcription were purchased from Invitrogen. The amplification conditions consisted of one denaturation/activation cycle at $95^{\circ} \mathrm{C}$ for $10 \mathrm{~min}$, followed by 40 cycles at $95^{\circ} \mathrm{C}$ for $15 \mathrm{~s}$ and $60^{\circ} \mathrm{C}$ for $60 \mathrm{~s}$. Serial dilutions of cDNA from the same source as the samples were used to obtain a standard curve. The $\mathrm{AT}_{1 \mathrm{a}}$ gene was quantified in each sample by determining the cycle threshold and comparing this value to the standard curve. The relative amount of the $\mathrm{AT}_{1 \mathrm{a}}$ mRNA was normalized to the amount of the housekeeping gene GAPDH.

\section{Terminal deoxynucleotidyl transferase dUTP nick end labeling (TUNEL) and DAPI staining}

To determine the apoptotic morphology of the CGCs, TUNEL was performed using the In Situ Cell Death Detection Kit Fluorescein (Roche Diagnostic) as previously described ${ }^{[28]}$. Briefly, the neuronal cells were cultured on poly-L-lysinecoated glass chamber slides and, after 6 or 7 DIV, were pretreated with telmisartan for $24 \mathrm{~h}$, followed by $24 \mathrm{~h}$ of B27 deprivation. The cells were then fixed with $4 \%$ paraformaldehyde. The cells were subsequently treated with $0.1 \%$ Triton X-100 in PBS for 2 min on ice and incubated with TUNEL reaction mixture for $60 \mathrm{~min}$ at $37^{\circ} \mathrm{C}$. After washing, the TUNELlabeled nuclei (green points) were examined using an inverted fluorescence microscope (model Olympus, Tokyo, Japan). After TUNEL, the nuclei were stained with DAPI $(1.5 \mu \mathrm{g} / \mathrm{mL})$, which was included in the mounting medium (Vectashield; Vector Laboratories, Burlingame, CA, USA) to yield blue fluorescent nuclear images. The labeled nuclei (blue points) were examined with a microscope (Olympus) equipped with a digital camera.

\section{DNA laddering assay}

The CGCs were pretreated with telmisartan for $24 \mathrm{~h}$, followed by nutrient deprivation. After $24 \mathrm{~h}$ of nutrient removal, the cells were pelleted, and total genomic DNA was extracted. DNA fragmentation was detected using the Apoptotic DNA Ladder Detection Kit (Millipore) according to the manufacturer's instruction.

\section{Statistical analysis}

Statistical significance was determined using the GraphPad Prism 5 Software (GraphPad Software, San Diego, CA, USA). Multiple group comparisons were performed using a one-way ANOVA, followed by Bonferroni post test. The differences were considered statistically significant at $P<0.05$. The values 
are expressed as the mean \pm SEM.

\section{Results}

Telmisartan protects neurons from nutrient deprivation-induced apoptotic cell death

Incubation of CGCs for $24 \mathrm{~h}$ under nutrient deprivation conditions by removing the B27 supplement (-B27) dramatically induced neuronal death, as indicated by an increase in LDH release and the number of dead cells, compared to the B27 supplemented (+B27) control cultures (Figure 1). Co-incubation of the B27-deprived neurons with $10 \mu \mathrm{mol} / \mathrm{L}$ telmisartan, candesartan or losartan partially reversed this effect, and of these inhibitors, telmisartan showed the most potent effect
(Figure 1A). The WST-1 assay was also simultaneously performed to evaluate the effects of the ARBs on cell viability, and telmisartan still exhibited the most potent neuroprotective effect (Figure 1B). Thus, telmisartan was selected for the following experiments. Telmisartan dose-dependently, even at a lower concentration of $1 \mu \mathrm{mol} / \mathrm{L}$, inhibited the B27 removal-induced $\mathrm{LDH}$ release (Figure $1 \mathrm{C}$ ) and reduced the number of dead cells (Figure 1D). To further demonstrate that telmisartan exerts anti-apoptotic actions on CGCs, we examined the TUNEL-positive cells, DNA laddering, and caspase-3 activation in control and B27-deprived cultures in the presence and absence of telmisartan. Removal of the B27 supplement induced an increase in the number of TUNEL-positive cells

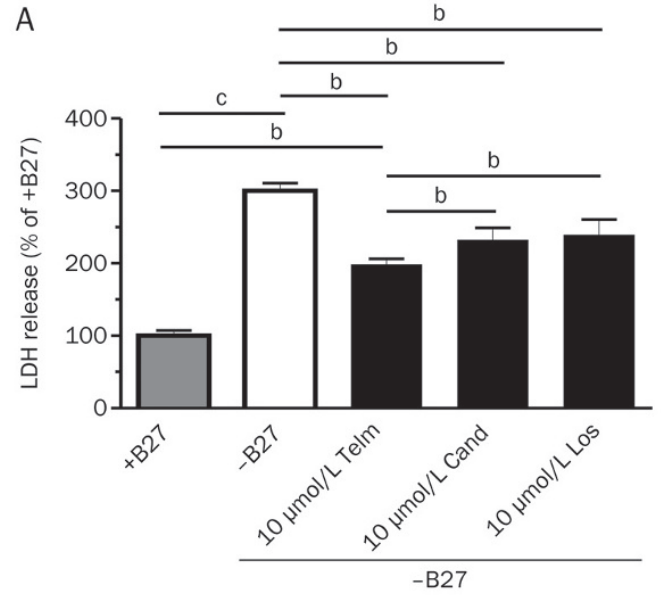

C

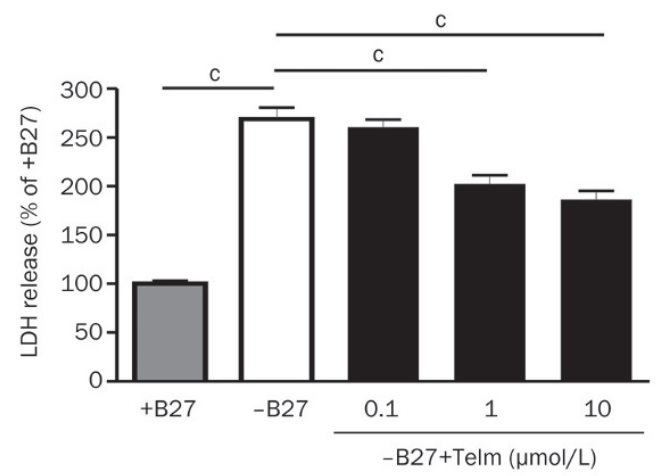

B
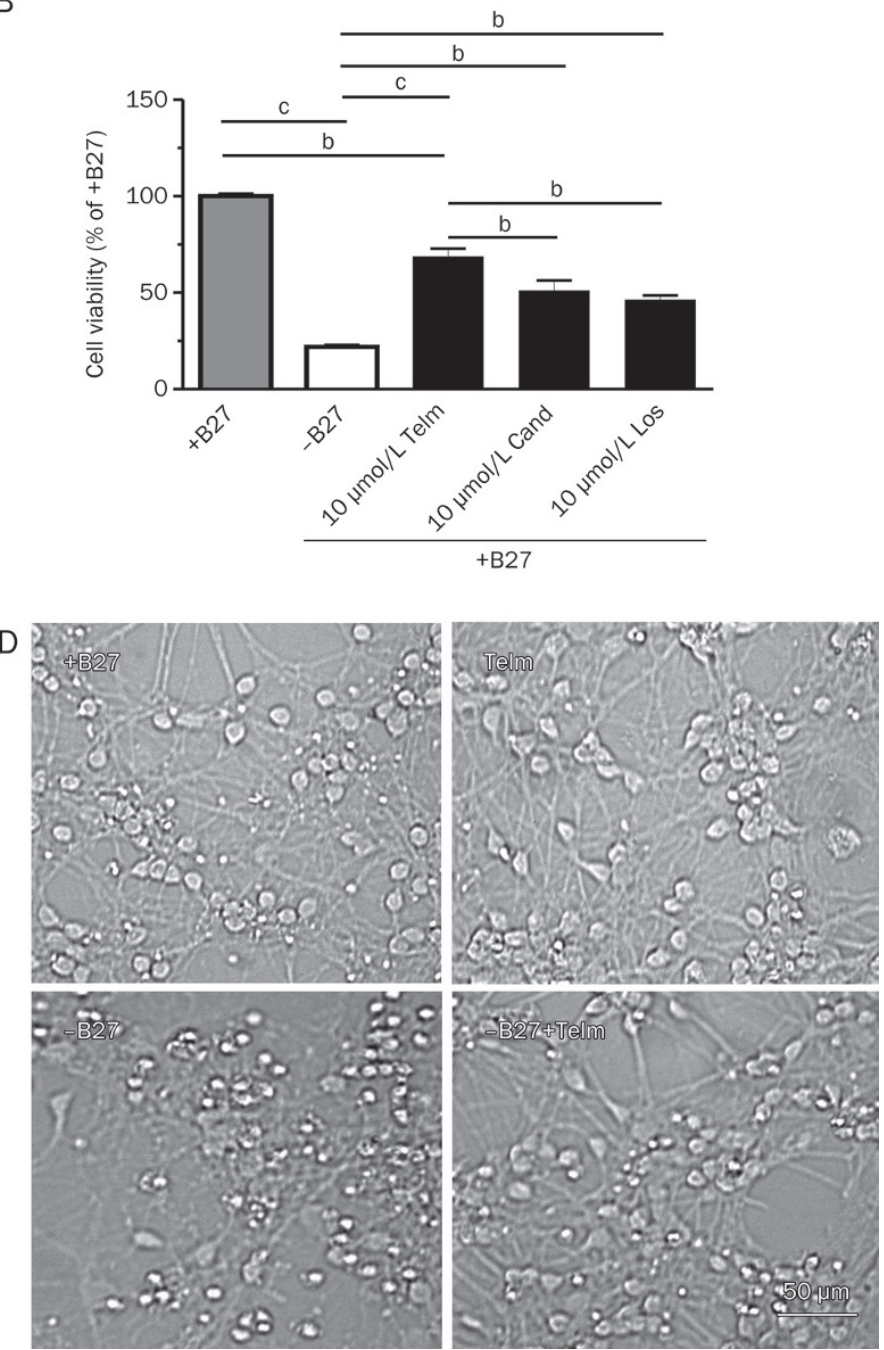

Figure 1. Telmisartan prevents nutrient deprivation-induced neuronal death in CGCs. (A, B) CGCs were pretreated with $10 \mu \mathrm{mol} / \mathrm{L}$ telmisartan (Telm), $10 \mu \mathrm{mol} / \mathrm{L}$ candesartan (Cand), or $10 \mu \mathrm{mol} / \mathrm{L}$ losartan (Los) for $24 \mathrm{~h}$, followed by B27 deprivation for an additional $24 \mathrm{~h}$. LDH release (A) in the culture supernatant was detected using the LDH Activity Assay kit, and cell viability was measured using the WST-1 assay (B) as described in Materials and methods. (C) CGCs were pretreated with different concentrations of telmisartan (Telm) for $24 \mathrm{~h}$, followed by incubation with or without B27. LDH release in the culture supernatant was measured using the LDH Activity Assay kit, as described in Materials and methods. (D) Morphology of the neurons. The cells were pretreated with $1 \mu \mathrm{mol} / \mathrm{L}$ telmisartan (Telm) for $24 \mathrm{~h}$, followed by the B27 deprivation for an additional $24 \mathrm{~h}$. Photomicrographs were taken using an inverted light microscope. Scale bar, $50 \mu \mathrm{m}$. The results represent the mean $\pm \mathrm{SEM}$ of at least three independent experiments. ${ }^{\mathrm{b}} P<0.05,{ }^{\mathrm{c} P}<0.01$. 
A
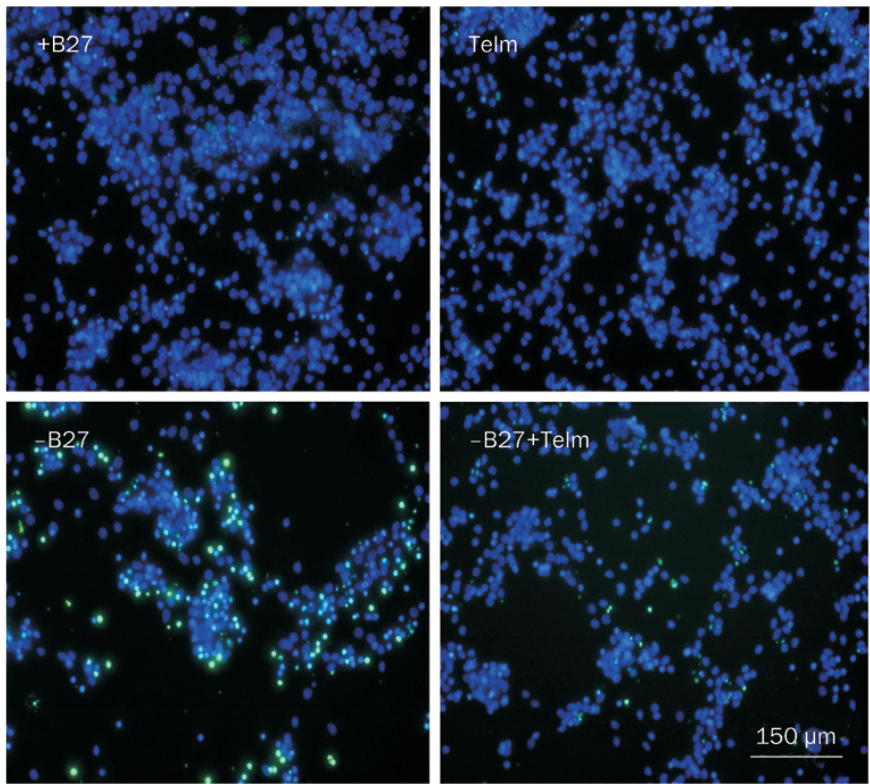

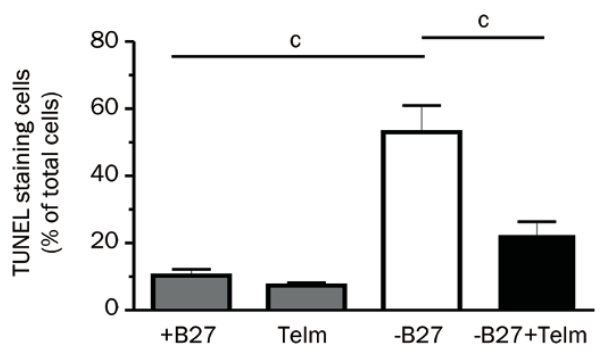

B

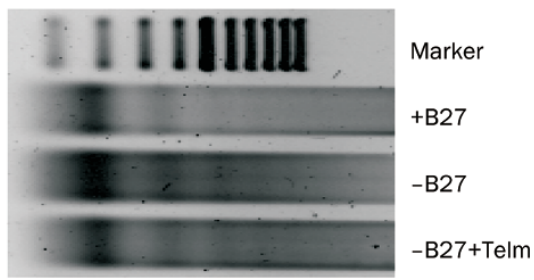

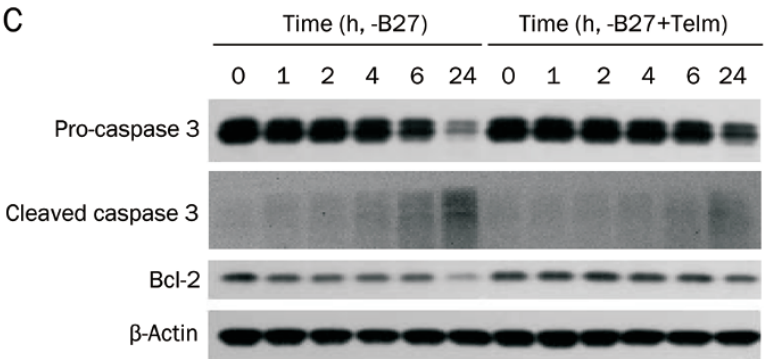
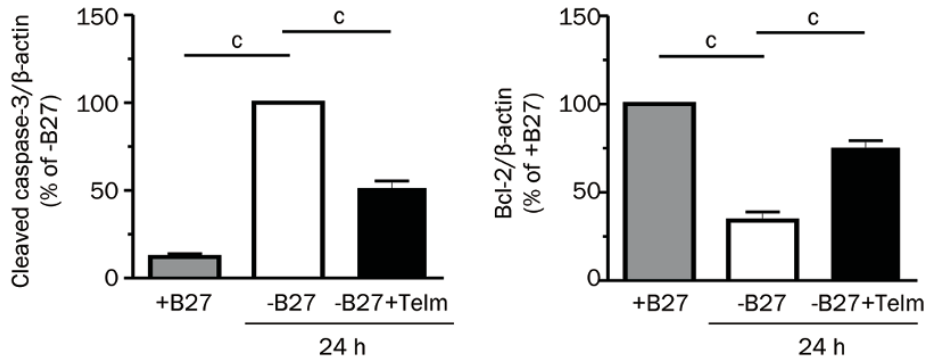

Figure 2. Telmisartan protects CGCs from nutrient deprivation-induced apoptosis. CGCs were pretreated with $1 \mu \mathrm{mol} / \mathrm{L}$ telmisartan (Telm) for $24 \mathrm{~h}$, followed by B27 deprivation for an additional $24 \mathrm{~h}$. Apoptosis was determined by the cell morphology using the In Situ Cell Death Detection Kit (A) and DNA laddering using the DNA fragmentation assay (B). The figure represents a typical experiment that was repeated three times. (C) CGCs were pretreated with or without $1 \mu \mathrm{mol} / \mathrm{L}$ Telm for $24 \mathrm{~h}$, followed by B27 deprivation for the indicated time points. The levels of the apoptotic protein caspase- 3 and the anti-apoptotic protein $\mathrm{Bcl}-2$ were determined using Western blot analysis. All results represent the mean \pm SEM of three independent experiments. ${ }^{\circ} P<0.01$.

(Figure 2A), DNA fragmentation levels (Figure 2B) and caspase- 3 activation, as indicated by caspase- 3 cleavage (Figure 2C). These effects were significantly reduced by co-incubation with telmisartan (Figure 2). B27 deprivation time-dependently decreased the level of the anti-apoptotic protein Bcl-2 (Figure 2C). Incubation with telmisartan partially reversed this effect, compared to the B27-deprived cultures without telmisartan (Figure 2C).

Telmisartan reverses the suppression of the Akt/GSK-3 $\beta$ pathway induced by nutrient deprivation in CGCs

As the Akt/GSK-3 $\beta$ signaling pathway has been well-studied as a survival-promoting signaling mechanism in neurons ${ }^{[29]}$, we investigated the involvement of these kinases in the neuroprotective effects of telmisartan. CGCs were B27 starved for different durations in the absence or presence of $1 \mu \mathrm{mol} / \mathrm{L}$ telmisartan. B27 deprivation decreased the phosphorylation levels of Akt (Ser473) and GSK-3 $\beta$ (Ser9), indicating a decrease in Akt activity and an increase in GSK-3 $\beta$ activity (Figure 3). Conversely, telmisartan reversed both of these effects (Figure 3).

The role of the $\mathrm{AT}_{1}$ receptor in the neuroprotective effects of telmisartan

B27 deprivation significantly enhanced $\mathrm{AT}_{1 \mathrm{a}}$ mRNA expression compared to the B27 incubation control (Figure 4A). The presence of telmisartan partially blocked the B27 deprivationinduced $\mathrm{AT}_{1 \mathrm{a}}$ mRNA expression (Figure $4 \mathrm{~A}$ ).

To further confirm the role of $\mathrm{AT}_{1 \mathrm{a}}$ receptor in the neuroprotective effect of telmisartan, $\mathrm{AT}_{1 \mathrm{a}}$-deficient CGCs isolated from $\mathrm{AT}_{1 \mathrm{a}}-\mathrm{KO}$ mice were used. The removal of the B27 supplement induced less $\mathrm{LDH}$ release in the CGCs from the $\mathrm{AT}_{1 \mathrm{a}} \mathrm{-KO}$ mice than in the CGCs from the wild-type control mice (Figure 4B). However, pretreatment with telmisartan or losartan prevented the nutrient B27 deprivation-induced LDH release in both the CGCs from the wild-type and $\mathrm{AT}_{1 \mathrm{a}}-\mathrm{KO}$ mice (Figure $4 \mathrm{~B}$ ), sug- 

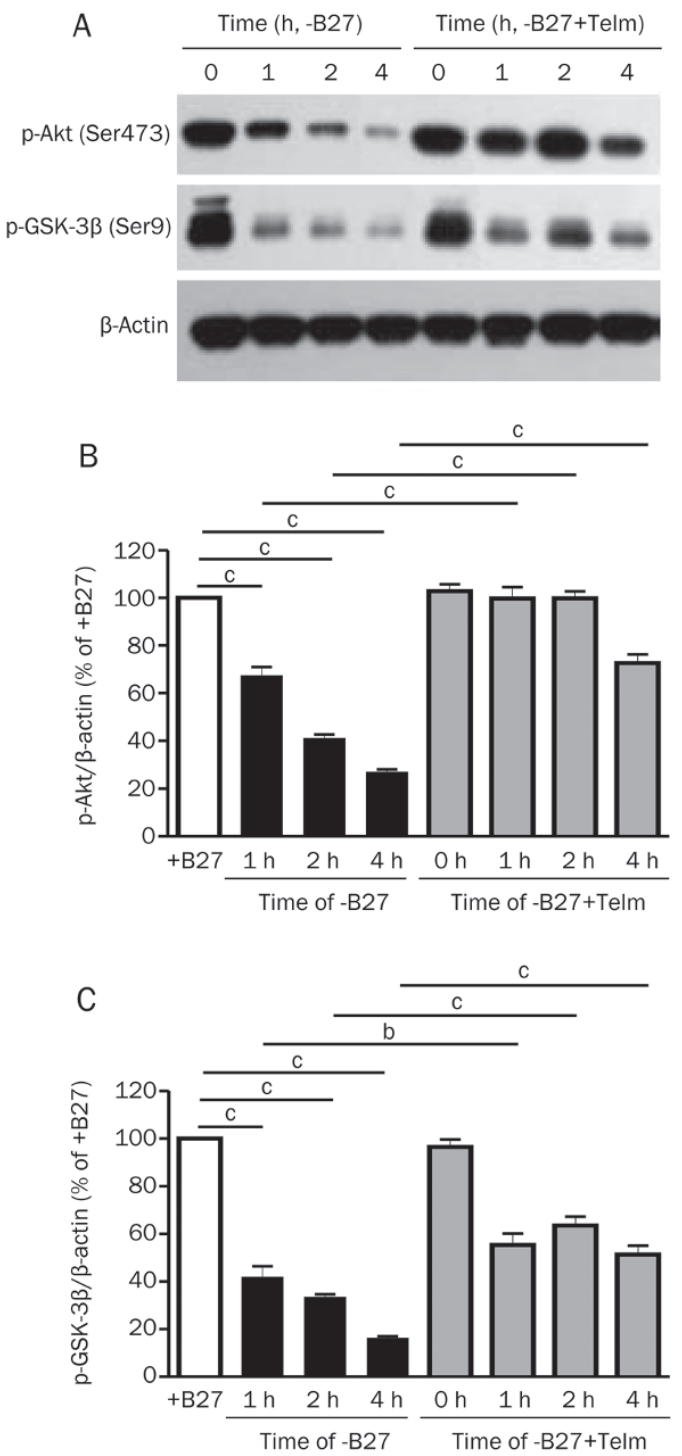

Figure 3. Telmisartan inhibits the nutrient deprivation-induced alterations in Akt and GSK-3ß phosphorylations. CGCs were pretreated with $1 \mu \mathrm{mol} / \mathrm{L}$ telmisartan (Telm) for $24 \mathrm{~h}$, followed by nutrient deprivation (-B27) for the indicated times. The levels of phosphorylated Akt (Ser473) (A, B) and GSK-3B (Ser9) (A, C) were determined using Western blot analysis. The results represent the mean \pm SEM of the groups from three independent experiments. ${ }^{\mathrm{c}} \mathrm{P}<0.01$.

gesting that both $\mathrm{AT}_{1}$ receptor-dependent and $\mathrm{AT}_{1}$-independent mechanisms are involved in the neuroprotective effects of telmisartan. The PPARY antagonist GW9662 partially reversed the preventive effects of telmisartan and losartan in the CGCs from the $\mathrm{AT}_{1 \mathrm{a}}-\mathrm{KO}$ mice (Figure $4 \mathrm{C}$ ).

Telmisartan's neuroprotective effects are partly mediated by the PPARy pathway in CGCs

As telmisartan also exhibits a PPARY activating property, the participation of the PPARY pathway in mediating the neuroprotective effects of telmisartan in CGCs was studied using the PPARY agonist pioglitazone and the antagonist GW9662. The
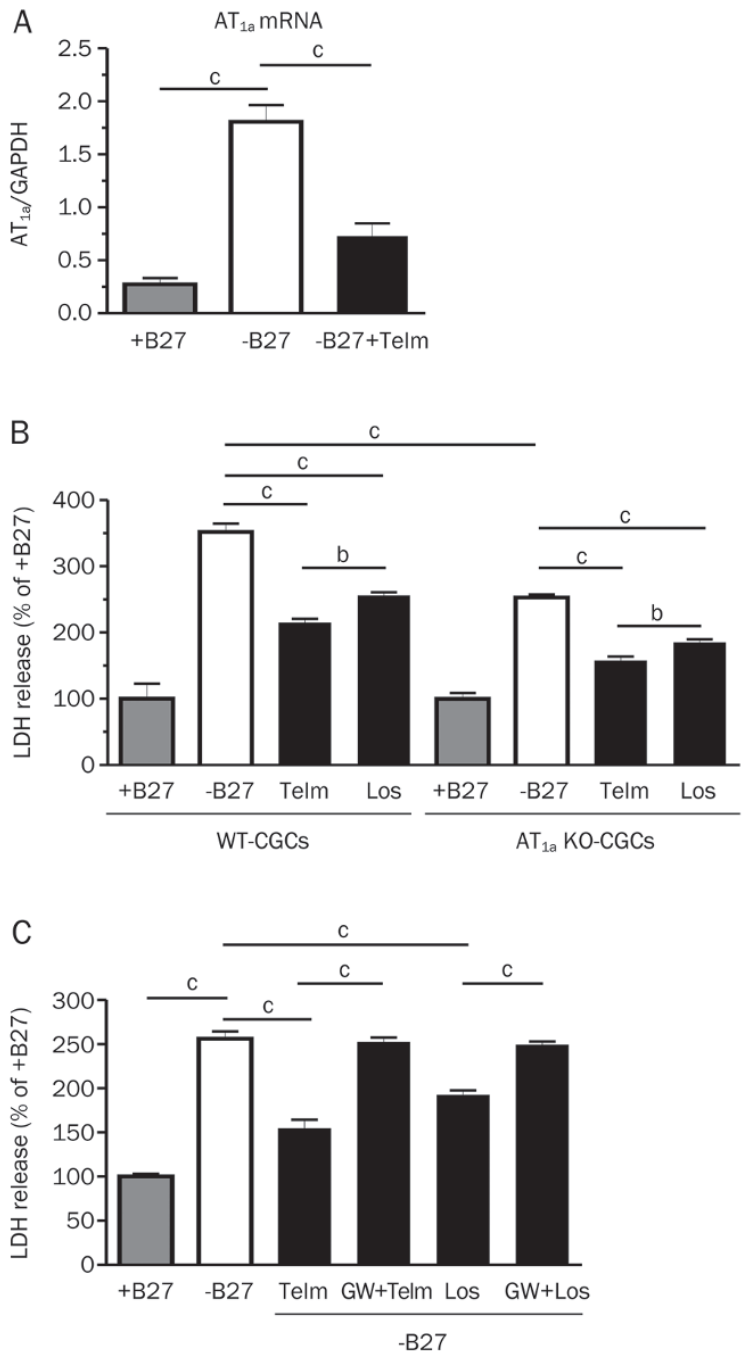

Figure 4. The $\mathrm{AT}_{1}$ receptor is involved in telmisartan neuroprotection. (A) CGCs were pretreated with $1 \mu \mathrm{mol} / \mathrm{L}$ telmisartan (Telm) for $24 \mathrm{~h}$, followed by $\mathrm{B} 27$ deprivation, and $\mathrm{AT}_{1 \mathrm{a}}$ gene expression was determined $24 \mathrm{~h}$ later. The data are presented as the mean \pm SEM of three independent experiments. ${ }^{c} P<0.01$. (B) Nutrient deprivation-induced neuronal death is reduced in CGCs isolated from $\mathrm{AT}_{1 \mathrm{a}}$ receptor knock-out mice $(\mathrm{KO})$ when compared to the wild-type mice (WT). Primary CGCs from wild-type or $\mathrm{AT}_{1 \mathrm{a}}$ knock-out mice were pretreated with $1 \mu \mathrm{mol} / \mathrm{L}$ Telm or $10 \mu \mathrm{mol} / \mathrm{L}$ losartan (Los) for $24 \mathrm{~h}$, followed by B27 deprivation for an additional $24 \mathrm{~h}$. The maximum nutrient deprivation-induced $L D H$ release was significantly lower in the CGCs obtained from the $\mathrm{AT}_{1 \mathrm{a}}$ knock-out mice compared to that from the wild-type mice. (C) Primary CGCs from the $\mathrm{AT}_{1 \mathrm{a}}$ knock-out mice were pretreated with $20 \mu \mathrm{mol} / \mathrm{L}$ GW9662 for $2 \mathrm{~h}$, followed by $24 \mathrm{~h}$ exposure to $1 \mu \mathrm{mol} / \mathrm{L}$ Telm or $10 \mu \mathrm{mol} / \mathrm{L}$ Los and B27 deprivation for an additional $24 \mathrm{~h}$ to determine the $\mathrm{LDH}$ release. The results represent the mean \pm SEM of the groups from three independent experiments. ${ }^{c} P<0.01$.

PPARY agonist pioglitazone decreased the B27 deprivationinduced LDH release and was more potent than telmisartan (Figure 5A). GW9662 totally prevented the protective action of telmisartan, while incubation with GW9662 alone had no effect on the B27 deprivation-induced neurotoxicity (Figure 5). GW9662 markedly decreased the telmisartan-induced inhibi- 
A

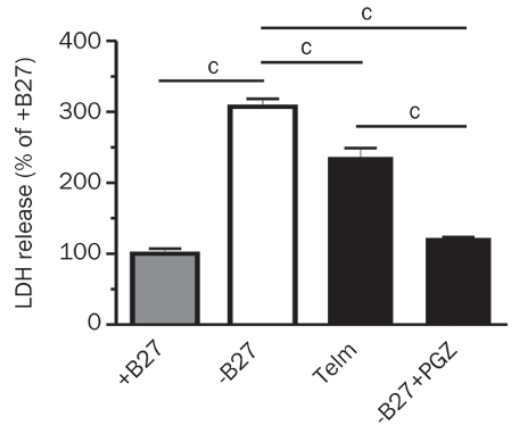

C

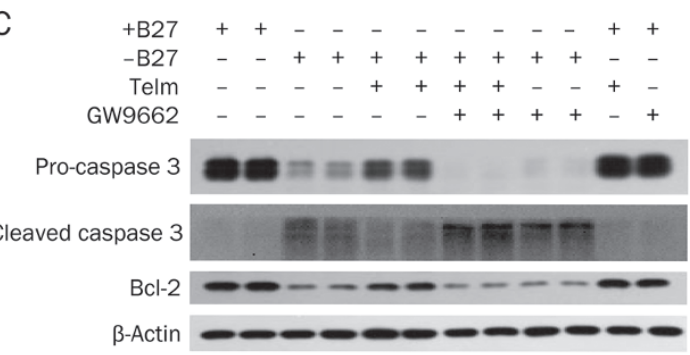

$\mathrm{D}$

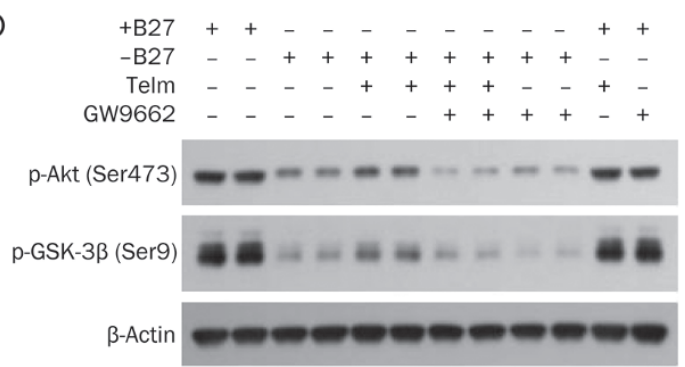

Figure 5. PPARy activation is partly involved in the neuroprotective effects of telmisartan in CGCs. (A) CGCs were pretreated with $1 \mu \mathrm{mol} / \mathrm{L}$ telmisartan (Telm) or $10 \mu \mathrm{mol} / \mathrm{L}$ PPARy agonist pioglitazone (PGZ) for $24 \mathrm{~h}$, followed by $\mathrm{B} 27$ deprivation for an additional $24 \mathrm{~h}$. (B) CGCs were pretreated with $1 \mu \mathrm{mol} / \mathrm{L}$ Telm for $24 \mathrm{~h}$, followed by B27 deprivation for an additional 24 h. The PPARy antagonist GW9662 (GW, $20 \mu \mathrm{mol} / \mathrm{L}$ ) was added $2 \mathrm{~h}$ prior to Telm treatment. (C, D) CGCs were pretreated with $20 \mu \mathrm{mol} / \mathrm{L}$ GW9662 for $2 \mathrm{~h}$, followed by $24 \mathrm{~h}$ exposure to $1 \mu \mathrm{mol} / \mathrm{L}$ Telm and B27 deprivation for an additional $24 \mathrm{~h}$ to determine the caspase- 3 activation, as indicated by caspase-3 cleavage, and $\mathrm{Bcl}-2$ expression using Western blot analysis (C). Alternatively, the cells were starved for $4 \mathrm{~h}$ to determine the phosphorylation levels of Akt and GSK-3 $\beta$ using Western blot analysis (D). One representative picture is presented here. The data are presented as the mean \pm SEM of three independent experiments. ${ }^{c} P<0.01$.
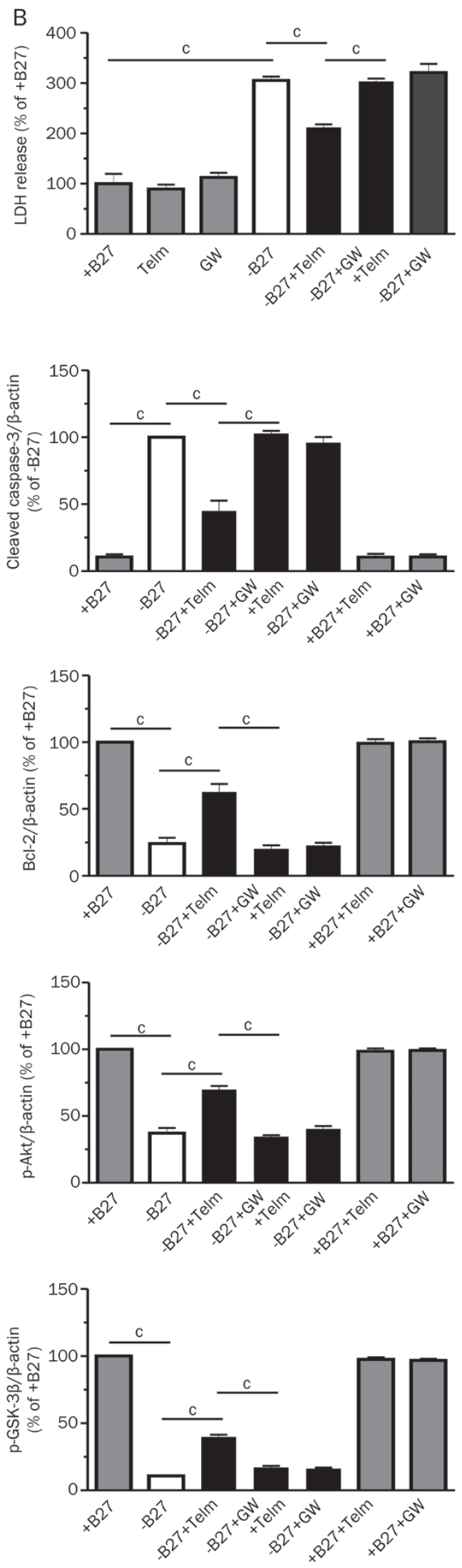
tion of B27 deprivation-induced LDH release (Figure 5B), caspase-3 activation (Figure 5C) and Bcl-2 down-regulation (Figure 5C). GW9662 remarkably blocked the telmisartan-induced increase in B27 deprivation-induced Akt activity, as indicated by Akt (Ser473) phosphorylation (Figure 5D), and prevented the telmisartan-induced inhibition of B27 deprivation-induced GSK-3 $\beta$ activity, as indicated by the levels of inactive, phosphorylated GSK-3 $\beta$ (Ser9) (Figure 5D).

\section{Discussion}

In this study, we used primary cultures of CGCs as an in vitro model to investigate the potential neuroprotective role of ARBs. We demonstrated that ARBs, in particular telmisartan, have protective effects against nutrient deprivation-induced apoptosis in CGCs, and activation of PPARY and the Akt/ GSK- $3 \beta$ signaling pathways are the main contributors to this effect.

In our preparations, these neuronal cells undergo apoptotic cell death after the removal of the culture supplement B27, as shown by increased DNA fragmentation, caspase- 3 activation and characteristic morphological changes. Nutrient deprivation-induced apoptosis plays an important pathophysiological role in the CNS after TBI, ischemia or many chronic neurodegenerative diseases ${ }^{[30-32]}$. Therefore, the ability of ARBs to ameliorate nutrient deprivation-mediated apoptosis might explain the therapeutic efficacy of ARBs and shed light on the mechanisms by which ARBs significantly ameliorate the neurological outcome of the TBI animal mode ${ }^{[23]}$, the stroke $\mathrm{e}^{[24]}$ or the Alzheimer's disease model ${ }^{[25]}$. The concentrations of telmisartan used in the present study ranged from 1 to 10 $\mu \mathrm{mol} / \mathrm{L}$ to prevent nutrient deprivation-induced apoptosis in CGCs, and these levels were clinically physiological ${ }^{[33]}$ and could be reached in the patient serum.

Ang II stimulates two receptor types, the $\mathrm{AT}_{1}$ and $\mathrm{AT}_{2}$ receptors ${ }^{[34]}$. Ang II attenuates neuronal cell death induced by glutamate primarily through the $\mathrm{AT}_{2}$ receptor ${ }^{[35,36]}$. CGCs expressed $\mathrm{AT}_{1}$ receptor mRNA, whereas there was no detectable $\mathrm{AT}_{2}$ receptor mRNA expression in the CGCs (data not shown), indicating that the $\mathrm{AT}_{1}$ receptor is involved in the neuroprotective effect of telmisartan in CGCs. Further indications of $\mathrm{AT}_{1}$ receptor's participation in the neurotoxic effect of nutrient deprivation included the upregulation of the $\mathrm{AT}_{1}$ receptor and the reduction of the nutrient deprivation-induced neurotoxicity in CGCs isolated from $\mathrm{AT}_{1 \mathrm{a}}-\mathrm{KO}$ mice, which do not express the $\mathrm{AT}_{1}$ receptor. A similar neuroprotective role for the $\mathrm{AT}_{1}$, but not $\mathrm{AT}_{2}$, receptor was reported earlier in human neuroblasts ${ }^{[37]}$.

There is evidence that some sartans, in addition to $\mathrm{AT}_{1}$ receptor blockade, activate the nuclear receptor PPARY, an important neuroprotective system ${ }^{[25,38,39]}$. Prolonged candesartan administration upregulates PPARY gene expression in adipose tissue ${ }^{[40]}$, and the beneficial effect of candesartan in a mouse model of TBI is partially the result of PPARY activation $^{[23]}$. Another sartan, losartan, has been reported to activate PPARY in vivo ${ }^{[41]}$ and in vitro ${ }^{[42]}$. However, the PPARY activating effect of telmisartan has been reported to be higher than that of candesartan or losartan ${ }^{[12,25,39,43]}$. When tested in primary cultures of CGCs obtained from wild-type or $\mathrm{AT}_{1 \mathrm{a}}-\mathrm{KO}$ mice, telmisartan was a far more potent neuroprotective agent than losartan which exhibited a reduced PPARY activating ability $^{[12,43]}$. Furthermore, incubation with a PPAR $\gamma$ antagonist partially reduced the neuroprotective effects of telmisartan and losartan in CGCs from $\mathrm{AT}_{1 \mathrm{a}}-\mathrm{KO}$ mice. This suggests that the PPARY activating effect of telmisartan or losartan is mainly responsible for its neuroprotective efficacy. These results are consistent with the initial demonstration of PPARY activation by telmisartan or losartan in cell cultures ${ }^{[12,42-44]}$, and the PPAR $\gamma$-activating neuroprotective effects of telmisartan or losartan in vivo ${ }^{[25,41,45,46]}$. It has also been reported that PPARY activation can promote neuroprotection against glutamatemediated neurotoxicity ${ }^{[47]}$, as well as reduce neuronal damage in focal cerebral ischemia ${ }^{[48,49]}$ and other neurodegenerative diseases, such as amyotrophic lateral sclerosis, Huntington's disease and Parkinson's disease ${ }^{[46,50,51]}$.

It has been well established that Akt phosphorylation is also associated with CGC survival ${ }^{[52,53]}$. It has been reported that the survival of CGCs after serum deprivation can be maintained by several different survival factors, all of which converge in the activation of $\mathrm{Akt}^{[54,55]}$. Telmisartan significantly increased the decreased Akt phosphorylation caused by nutrient deprivation in CGCs, suggesting that the activation of the PI-3K/Akt pathway by telmisartan plays an important role in enhancing cell survival. This pathway also delivers an antiapoptotic signal. Bcl-2, one of the downstream targets of Akt, is an anti-apoptotic molecule that maintains the mitochondrial membrane potential and prevents the release of cytochrome $c$ from the mitochondria ${ }^{[56,57]}$. Our results showed that telmisartan was able to increase the level of Bcl-2 protein to prevent nutrient deprivation-induced neuronal death. The PPARY agonist rosiglitazone has been shown to prevent $\beta$-amyloidinduced neurodegeneration in hippocampal neurons through a mechanism involving the increased expression of Bcl-2 ${ }^{[58]}$. Therefore, the upregulation of Bcl-2 protein due to PPARY activation might be one of the important mechanisms responsible for the neuroprotective effect of telmisartan.

GSK-3 $\beta$, a serine/threonine kinase, is abundant in the CNS and plays a pivotal role in the regulation of numerous cellular functions. GSK-3 $\beta$ is another downstream target of Akt and regulates many metabolic and signaling proteins that can influence cell survival and the expression of a variety of genes associated with cellular metabolism ${ }^{[59]}$. Akt phosphorylates GSK-3 $\beta$ at serine 9 to inactivate the GSK-3 $\beta$ kinase, and this inactivation occurs during neuronal degeneration ${ }^{[60]}$. Conversely, the inactivation of GSK-3 $\beta$ by PI3K/Akt has been shown to be an important neuroprotective mechanism. Our results showed that nutrient deprivation decreased the level of GSK-3 $\beta$ phosphorylation at serine 9 (inactive form) in a time-dependent manner, which is consistent with previously reported studies which showed that GSK-3 $\beta$ activation-mediated neuronal apoptosis could be induced by trophic factor withdrawal ${ }^{[26,61-63]}$. Telmisartan increased the level of inactive GSK-3 $\beta$ in the CGCs. Therefore, the inhibition of GSK-3 $\beta$ is 
neuroprotective ${ }^{[22,62-65]}$, and the activation of the Akt/GSK-3 $\beta$ signaling pathway mediates neuronal survival to reduce neuronal death resulting from oxygen-glucose deprivation, glutamate excitotoxicity and cerebral ischemia ${ }^{[64-66]}$.

In summary, the data obtained in the present study show that telmisartan exerts its neuroprotective effect against nutrient deprivation-induced apoptosis in CGCs through $\mathrm{AT}_{1}$ receptor blockade and PPARY activation, and these effects involved the activation of the Akt/GSK-3 $\beta$ pathway, which is activated by telmisartan, resulting in the observed neuroprotective effects, as illustrated in Figure 6. Our results support the hypothesis that ARBs, in particular telmisartan, could have therapeutic potential for brain diseases in which nutrient insufficiency plays an important role in neurotoxicity.

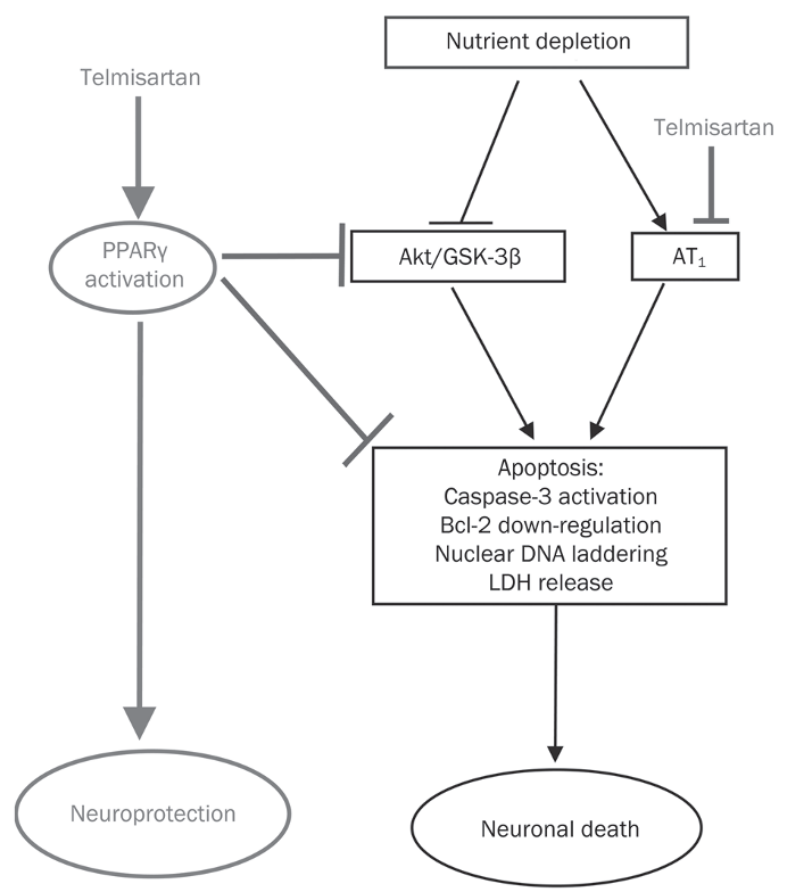

Figure 6. Proposed mechanisms of telmisartan neuroprotection. Nutrient depletion induces neuronal injury by stimulating apoptosis. The involved mechanisms include increasing the expression of the $\mathrm{AT}_{1}$ receptor and inhibiting the anti-apoptotic Akt/GSK-3 $\beta$ pathway. Telmisartan reduces nutrient depletion-induced neuronal apoptosis in CGCs. Telmisartan neuroprotection is due to both $\mathrm{AT}_{1}$ receptor blockade and PPARy activation, which decreases apoptosis by preventing the nutrient deprivation-induced alterations in the Akt/GSK-3ß pathway.

\section{Acknowledgements}

This study was supported by the Natural Science Foundation of Jiangsu Province (BK20130653, BK2010433), the Fundamental Research Funds for the Central Universities (JKZD2013006), the National Natural Science Foundation of China (81070967, 81271338), the Specialized Research Fund for the Doctoral Program of Higher Education of China (20130096110011) and the Initial Fund of China Pharmaceutical University to Dr Tao PANG.

\section{Author contribution}

Tao PANG, Hong LIAO and Lu-yong ZHANG designed the research. Tao PANG, Li-xin SUN, Tao WANG and Zhenzhou JIANG performed the research. Tao PANG, Li-xin SUN, Hong LIAO and Lu-yong ZHANG analyzed the data, and Tao PANG wrote the paper.

\section{Abbreviations}

Ang II, angiotensin II; Akt, protein kinase B; ARB, angiotensin II receptor blocker; $\mathrm{AT}_{1}$, Angiotensin II receptor type 1; $\mathrm{AT}_{2}$, Angiotensin II receptor type 2; Bcl-2, B-cell leukemia/ lymphoma 2; CGCs, cerebellar granule neuronal cells; DAPI, 4',6-diamidino-2-phenylindole; GSK-3 $\beta$, glycogen synthase kinase 3 beta; LDH, lactate dehydrogenase; PI3K, phosphoinositide 3-kinase; PPAR $\gamma$, peroxisome proliferator-activated receptor gamma; RAS, renin-angiotensin system; TBI, traumatic brain injury; TUNEL, terminal deoxynucleotidyl transferase dUTP nick end labeling.

\section{References}

1 Dzau VJ, Ingelfinger J, Pratt RE, Ellison KE. Identification of renin and angiotensinogen messenger RNA sequences in mouse and rat brains. Hypertension 1986; 8: 544-8.

2 Gyurko R, Wielbo D, Phillips MI. Antisense inhibition of AT1 receptor mRNA and angiotensinogen mRNA in the brain of spontaneously hypertensive rats reduces hypertension of neurogenic origin. Regul Pept 1993; 49: 167-74.

3 Inaba S, Iwai M, Tomono Y, Senba I, Furuno M, Kanno H, et al. Exaggeration of focal cerebral ischemia in transgenic mice carrying human renin and human angiotensinogen genes. Stroke 2008; 40: $597-$ 603.

4 Wright JW, Yamamoto BJ, Harding JW. Angiotensin receptor subtype mediated physiologies and behaviors: new discoveries and clinical targets. Prog Neurobiol 2008; 84: 157-81.

5 AbdAlla S, Lother H, el Missiry A, Langer A, Sergeev P, el Faramawy, et al. Angiotensin II AT2 receptor oligomers mediate G-protein dysfunction in an animal model of Alzheimer disease. J Biol Chem 2009; 284: 6554-65.

6 Kehoe PG, Miners S, Love S. Angiotensins in Alzheimer's diseasefriend or foe? Trends Neurosci 2009; 32: 619-28.

7 Joglar B, Rodriguez-Pallares J, Rodriguez-Perez Al, Rey P, Guerra MJ, Labandeira-Garcia JL. The inflammatory response in the MPTP model of Parkinson's disease is mediated by brain angiotensin: relevance to progression of the disease. J Neurochem 2009; 109: 656-69.

8 Schrader J, Lüders S, Kulschewski A, Berger J, Zidek W, Treib J, et al. Acute candesartan cilexetil therapy in Stroke Survivors Study group. The ACCESS study: evaluation of acute candesartan cilexetil therapy in stroke survivors. Stroke 2003; 34: 1699-703.

9 Schrader J, Lüders S, Kulschewski A, Hammersen F, Plate K, Berger J, et al. MOSES Study Group. Morbidity and mortality after stroke, Eprosartan compared with nitrendipine for secondary prevention: principal results of a prospective randomized controlled study (MOSES). Stroke 2005; 36: 1218-26.

10 Krikov M, Thone-Reineke C, Müller S, Villringer A, Unger T. Candesartan but not ramipril pretreatment improves outcome after stroke and stimulates neurotrophin BNDF/TrkB system in rats. J Hypertens 2008; 26: 544-52.

11 Neldam S. Choosing an angiotensin-receptor blocker: blood pressure lowering, cardiovascular protection or both? Future Cardiol 2010; 6: 
129-35.

12 Benson SC, Pershadsingh HA, Ho Cl, Chittiboyina A, Desai P, Pravenec $\mathrm{M}$, et al. Identification of telmisartan as a unique angiotensin II receptor antagonist with selective PPARgamma-modulating activity. Hypertension 2004; 43: 993-1002.

13 Rotman N, Wahli W. PPAR modulation of kinase-linked receptor signaling in physiology and disease. Physiology (Bethesda) 2010; 25 : 176-85.

14 Chen YC, Wu JS, Tsai HD, Huang CY, Chen JJ, Sun GY, et al. Peroxisome proliferator-activated receptor gamma (PPAR-Y) and neurodegenerative disorders. Mol Neurobiol 2012; 46: 114-24.

15 Raff MC, Barres BA, Burne JF, Coles HS, Ishizaki Y, Jacobson MD. Programmed cell death and the control of cell survival: lessons from the nervous system. Science 1993; 262: 695-700.

16 Park DS, Levine B, Ferrari G, Greene LA. Cyclin dependent kinase inhibitors and dominant negative cyclin dependent kinase 4 and 6 promote survival of NGF-deprived sympathetic neurons. J Neurosci 1997; 17: 8975-83.

17 Hetman M, Kanning K, Cavanaugh JE, Xia Z. Neuroprotection by brain-derived neurotrophic factor is mediated by extracellular signalregulated kinase and phosphatidylinositol 3-kinase. J Biol Chem 1999; 274: 22569-80.

18 Moule SK, Welsh GI, Edgell NJ, Foulstone EJ, Proud CG, Denton RM. Regulation of protein kinase $B$ and glycogen synthase kinase-3 by insulin and beta-adrenergic agonists in rat epididymal fat cells. Activation of protein kinase $B$ by wortmannin-sensitive and -insensitive mechanisms. J Biol Chem 1997; 272: 7713-9.

19 Pap M, Cooper GM. Role of glycogen synthase kinase-3 in the phosphatidylinositol 3-kinase/Akt cell survival pathway. J Biol Chem 1998; 273: 19929-32.

20 Kawasaki H, Morooka T, Shimohama S, Kimura J, Hirano T, Gotoh Y, et al. Activation and involvement of p38 mitogen-activated protein kinase in glutamate-induced apoptosis in rat cerebellar granule cells. J Biol Chem 1997; 272: 18518-21.

21 Chalecka-Franaszek E, Chuang DM. Lithium activates the serine/ threonine kinase Akt-1 and suppresses glutamate-induced inhibition of Akt-1 activity in neurons. Proc Natl Acad Sci (USA) 1999; 96: 8745-50.

22 Leng $Y$, Liang MH, Ren M, Marinova Z, Leeds P, Chuang DM. Synergistic neuroprotective effects of lithium and valproic acid or other histone deacetylase inhibitors in neurons: roles of glycogen synthase kinase-3 inhibition. J Neurosci 2008; 28: 2576-88.

23 Villapol S, Yaszemski AK, Logan TT, Sánchez-Lemus E, Saavedra JM, Symes AJ. Candesartan, an angiotensin II AT(1)-receptor blocker and PPAR-y agonist, reduces lesion volume and improves motor and memory function after traumatic brain injury in mice. Neuropsychopharmacology 2012; 37: 2817-29.

24 Kasahara Y, Taguchi A, Uno H, Nakano A, Nakagomi T, Hirose H. Telmisartan suppresses cerebral injury in a murine model of transient focal ischemia. Brain Res 2010; 1340: 70-80.

25 Tsukuda K, Mogi M, Iwanami J, Min LJ, Sakata A, Jing F, et al. Cognitive deficit in amyloid-beta-injected mice was improved by pretreatment with a low dose of telmisartan partly because of peroxisome proliferator-activated receptor-gamma activation. Hypertension 2009; 54: 782-7.

26 Hetman M, Cavanaugh JE, Kimelman D, Xia Z. Role of glycogen synthase kinase-3beta in neuronal apoptosis induced by trophic withdrawal. J Neurosci 2000; 20: 2567-74.

27 Benicky J, Sánchez-Lemus E, Honda M, Pang T, Orecna M, Wang $\mathrm{J}$, et al. Angiotensin II AT1 receptor blockade ameliorates brain inflammation. Neuropsychopharmacology 2011; 36: 857-70.
28 Jantas D, Lorenc-Koci E, Kubera M, Lason W. Neuroprotective effects of MAPK/ERK1/2 and calpain inhibitors on lactacystin-induced cell damage in primary cortical neurons. Neurotoxicology 2011; 32: 84556.

29 Yuan J, Yankner BA. Apoptosis in the nervous system. Nature 2000; 407: 802-9.

30 Lee SM, Wong MD, Samii A, Hovda DA. Evidence for energy failure following irreversible traumatic brain injury. Ann N Y Acad Sci 1999; 893: 337-40.

31 Chiong M, Wang ZV, Pedrozo Z, Cao DJ, Troncoso R, Ibacache M, et al. Cardiomyocyte death: mechanisms and translational implications. Cell Death Dis 2011; 2: e244.

32 Seneff S, Wainwright G, Mascitelli L. Nutrition and Alzheimer's disease: the detrimental role of a high carbohydrate diet. Eur J Intern Med 2011; 22: 134-40.

33 Stangier J, Su CA, Roth W. Pharmacokinetics of orally and intravenously administered telmisartan in healthy young and elderly volunteers and in hypertensive patients. J Int Med Res 2000; 28 : 149-67.

34 de Gasparo M, Catt KJ, Inagami T, Wright JW, Unger T. International union of pharmacology. XXIII. The angiotensin II receptors. Pharmacol Rev 2000; 52: 415-72.

35 Jing G, Grammatopoulos T, Ferguson P, Schelman W, Weyhenmeyer J. Inhibitory effects of angiotensin on NMDA-induced cytotoxicity in primary neuronal cultures. Brain Res Bull 2004; 62: 397-403.

36 Schelman WR, Andres R, Ferguson P, Orr B, Kang E, Weyhenmeyer JA. Angiotensin II attenuates NMDA receptor-mediated neuronal cell death and prevents the associated reduction in $\mathrm{Bcl}-2$ expression. Brain Res Mol Brain Res 2004; 128: 20-9.

37 Pang T, Wang J, Benicky J, Sánchez-Lemus E, Saavedra JM. Telmisartan directly ameliorates the neuronal inflammatory response to IL-1ß partly through the JNK/c-Jun and NADPH oxidase pathways. J Neuroinflammation 2012; 9: 102.

38 Sauerbeck A, Gao J, Readnower R, Liu M, Pauly JR, Bing G, et al. Pioglitazone attenuates mitochondrial dysfunction, cognitive impairment, cortical tissue loss, and inflammation following traumatic brain injury. Exp Neurol 2011; 227: 128-35.

39 Min LJ, Mogi M, Shudou M, Jing F, Tsukuda K, Ohshima K, et al. Peroxisome proliferator-activated receptor-gamma activation with angiotensin II type 1 receptor blockade is pivotal for the prevention of blood-brain barrier impairment and cognitive decline in type 2 diabetic mice. Hypertension 2012; 59: 1079-88.

40 Zorad S, Dou J, Benicky J, Hutanu D, Tybitanclova K, Zhou J, et al. Long-term angiotensin II AT1 receptor inhibition produces adipose tissue hypotrophy accompanied by increased expression of adiponectin and PPARy. Eur J Pharm 2006; 552: 112-22.

41 Koh EJ, Yoon SJ, Lee SM. Losartan protects liver against ischemiareperfusion injury through PPARy activation and receptor for advanced glycation end-products down-regulation. Br J Pharmacol 2013; 169: 1404-16.

42 An J, Nakajima T, Kuba K, Kimura A. Losartan inhibits LPS-induced inflammatory signaling through a PPARgamma-dependent mechanism in human THP-1 macrophages. Hypertens Res 2010; 33: 831-5.

43 Erbe DV, Gartrell K, Zhang YL, Suri V, Kirincich SJ, Will S, et al. Molecular activation of PPARgamma by angiotensin II type 1-receptor antagonists. Vascul Pharmacol 2006; 45: 154-62.

44 Pang T, Benicky J, Wang J, Orecna M, Sanchez-Lemus E, Saavedra JM. Telmisartan ameliorates lipopolysaccharide-induced innate immune response through peroxisome proliferator-activated receptor- $\mathrm{Y}$ activation in human monocytes. J Hypertens 2012; 30: 87-96.

45 Iwanami J, Mogi M, Tsukuda K, Min L, Sakata A, Jing F, et al. Low 
dose of telmisartan prevents ischemic brain damage with peroxisome proliferator-activated receptor-gamma activation in diabetic mice. J Hypertens 2010; 28: 1730-7.

46 Garrido-Gil P, Joglar B, Rodriguez-Perez Al, Guerra MJ, LabandeiraGarcia JL. Involvement of PPAR-y in the neuroprotective and antiinflammatory effects of angiotensin type 1 receptor inhibition: effects of the receptor antagonist telmisartan and receptor deletion in a mouse MPTP model of Parkinson's disease. J Neuroinflammation 2012; 9: 38.

47 Zhao X, Ou Z, Grotta JC, Waxham N, Aronowski J. Peroxisomeproliferator-activated receptor-gamma (PPARgamma) activation protects neurons from NMDA excitotoxicity. Brain Res 2006; 10731074: 460-9.

48 Zhao Y, Patzer A, Herdegen T, Gohlke P, Culman J. Activation of cerebral peroxisome proliferator-activated receptors gamma promotes neuroprotection by attenuation of neuronal cyclooxygenase-2 overexpression after focal cerebral ischemia in rats. FASEB J 2006; 20 : 1162-75.

49 Zuhayra M, Zhao Y, von Forstner C, Henze E, Gohlke P, Culman J, et al. Activation of cerebral peroxisome proliferator-activated receptors Y (PPARy) reduces neuronal damage in the substantia nigra after transient focal cerebral ischaemia in the rat. Neuropathol Appl Neurobiol 2011; 37: 738-52.

50 Kiaei M, Kipiani K, Chen J, Calingasan NY, Beal MF. Peroxisome proliferator-activated receptor-gamma agonist extends survival in transgenic mouse model of amyotrophic lateral sclerosis. Exp Neurol 2005; 191: 331-6.

51 Kiaei M. Peroxisome proliferator-activated receptor-gamma in amyotrophic lateral sclerosis and Huntington's disease. PPAR Res 2008; 2008: 418765.

52 Finkbeiner S. CREB couples neurotrophin signals to survival messages. Neuron 2000; 25: 11-4.

53 Zhu D, Jiang X, Wu X, Tian F, Mearow K, Lipsky RH, et al. Inhibition of protein kinase $C$ promotes neuronal survival in low potassium through an Akt-dependent pathway. Neurotox Res 2004; 6: 281-9.

54 Vaillant AR, Mazzoni I, Tudan C, Boudreau M, Kaplan DR, Miller FD. Depolarization and neurotrophins converge on the phosphatidylinositol 3-kinase-Akt pathway to synergistically regulate neuronal survival. J Cell Biol 1999; 146: 955-66.

55 Kumari S, Liu X, Nguyen T, Zhang X, D'Mello SR. Distinct phosphorylation patterns underlie Akt activation by different survival factors in neurons. Brain Res Mol Brain Res 2001; 96: 157-62.

56 Wang LX, Sun Y, Chen C, Huang XY, Lin Q, Qian GQ, et al. Effects and mechanism of oridonin on pulmonary hypertension induced by chronic hypoxia-hypercapnia in rats. Chin Med J (Engl) 2009; 122: 1380-7.

57 Gross A, McDonnell JM, Korsmeyer SJ. BCL-2 family members and the mitochondria in apoptosis. Genes Dev 1999; 13: 1899-911.

58 Fuenzalida K, Quintanilla R, Ramos P, Piderit D, Fuentealba RA, Martinez G, et al. Peroxisome proliferator-activated receptor gamma up-regulates the $\mathrm{Bcl}-2$ anti-apoptotic protein in neurons and induces mitochondrial stabilization and protection against oxidative stress and apoptosis. J Biol Chem 2007; 282: 37006-15.

59 Cross DA, Alessi DR, Cohen P, Andjelkovich M, Hemmings BA. Inhibition of glycogen synthase kinase-3 by insulin mediated by protein kinase B. Nature 1995; 378: 785-9.

60 Bhat RV, Shanley J, Correll MP, Fieles WE, Keith RA, Scott CW, et al. Regulation and localization of tyrosine216 phosphorylation of glycogen synthase kinase-3beta in cellular and animal models of neuronal degeneration. Proc Natl Acad Sci USA 2000; 97: 11074-9.

61 Jin N, Kovács AD, Sui Z, Dewhurst S, Maggirwar SB. Opposite effects of lithium and valproic acid on trophic factor deprivation-induced glycogen synthase kinase-3 activation, c-Jun expression and neuronal cell death. Neuropharmacology 2005; 48: 576-83.

62 Chuang DM, Wang Z, Chiu CT. GSK-3 as a target for lithium-induced neuroprotection against excitotoxicity in neuronal cultures and animal models of ischemic stroke. Front Mol Neurosci 2011; 4: 15.

63 Liang MH, Chuang DM. Regulation and function of glycogen synthase kinase-3 isoforms in neuronal survival. J Biol Chem 2007; 282: 3904-17.

64 Liu F, Gong X, Zhang G, Marquis K, Reinhart P, Andree TH. The inhibition of glycogen synthase kinase 3 beta by a metabotropic glutamate receptor 5 mediated pathway confers neuroprotection to Abeta peptides. J Neurochem 2005; 95: 1363-72.

65 Kelly S, Zhao H, Hua Sun G, Cheng D, Qiao Y, Luo J, et al. Glycogen synthase kinase 3beta inhibitor Chir025 reduces neuronal death resulting from oxygen-glucose deprivation, glutamate excitotoxicity, and cerebral ischemia. Exp Neurol 2004; 188: 378-86.

66 Endo H, Nito C, Kamada H, Nishi T, Chan PH. Activation of the Akt/GSK3beta signaling pathway mediates survival of vulnerable hippocampal neurons after transient global cerebral ischemia in rats. J Cereb Blood Flow Metab 2006; 26: 1479-89. 